UDC 621.039

Doi: https://doi.org/10.32918/nrs.2019.2(82).08

\title{
Water Hammers in Transonic Modes of Steam-Liquid Flows in NPP Equipment
}

Skalozubov V.

Odesa National Polytechnic University, Odesa, Ukraine ORCID:https://orcid.org/0000-0003-2361-223X

Bilous N.

Odesa National Polytechnic University, Odesa, Ukraine ORCID:https://orcid.org/0000-0001-8492-4152

Pirkovskiy D.

Odesa National Polytechnic University, Odesa, Ukraine ORCID:https://orcid.org/0000-0002-6638-9499

Kozlov I.

Odesa National Polytechnic University, Odesa, Ukraine ORCID:https://orcid.org/0000-0003-0435-6373

Komarov Yu.

Odesa National Polytechnic University, Odesa, Ukraine ORCID:https://orcid.org/0000-0002-4696-6551

Chulkin O.

Odesa National Polytechnic University, Odesa, Ukraine ORCID:https://orcid.org/0000-0001-5048-4515

The analysis of well-known studies in modelling conditions for water hammers in equipment and components of pipeline systems has revealed that definition of conditions and parameters of water hammers in the transonic modes of single- and two-phase flows (at a speed of propagation of acoustic disturbances) is the least studied problem.

The original method is proposed for determining the conditions and parameters of water hammers in transonic flow modes subject to the transition of the kinetic energy of the flow stagnation into the energy of the water hammer pulse.

It was found that the simulated hydrodynamic loads in transonic modes can significantly exceed the corresponding known recommendations of N. Zhukovsky.

The proposed method of equations computer modelling served to determine the criteria range for water hammers due to aperiodic thermohydrodynamic instability in transonic flow modes.

Ke y wo rds: waterhammer, transonic modes, head-flowcharacteristic.

(C) Skalozubov V., Bilous N., Pirkovskiy D., Kozlov I., Komarov Yu., Chulkin O., 2019
$\mathrm{U}$ sually the water hammer (WH) means pulse highamplitude hydrodynamic impact on equipment/ elements of pipeline systems. WHs can significantly affect reliability, operability, a vibration state and wear of the equipment of nuclear power plants (NPP).

A lot of research is devoted to definition of the reasons, conditions and consequences of $\mathrm{WH}$ in the single-phase flow modes (for example, $[1-10]$, etc.). The accelerated closing of armature, inertia of the head-flow characteristic of pumps, resonant effects, etc. is considered as basic reasons of WHs. Generally, WH in single-phase flows is a result of different kinds of high-amplitude oscillatory or aperiodic hydrodynamic instability (for example, [9, 10]).

Inhomogeneity of a flow structure, intensive processes of an interphase heat and mass exchange and other factors (for example, $[11-16]$, etc.) that are a result of different kinds of oscillatory and aperiodic thermohydrodynamic instability of two-phase flows are basic reasons of WHs in two-phase flows.

The problem of WHs in two-phase transonic flows at the speed close to sonic speed (or the speed of propagation of acoustic disturbances) is the least studied. Feature of this phenomenon is that under certain conditions sonic speed in the steamliquid medium can be much less than in a steam (for example, $[12,15])$. When flow rate exceeds sonic speed there is a sharp stagnation of flow and kinetic energy of a flow transfers into WH pulse energy - "condensation shock". The transonic flow modes can be in the minimum throat areas of the equipment and elements of pipeline systems at NPP. Therefore modelling of WH conditions in transonic flows is an actual problem.

\section{Basic provisions and results of modelling of water hammers in transonic flows}

The pipeline system with the local hydrodynamic resistance (armature, throttle devices, pumps/compressors, etc.) with the variable throat area of a two-phase steam-liquid flow is modelled (Fig. 1). The adiabatic flashing flow in setting of the local hydrodynamic resistance (LHR) is modelled in one-dimensional and quasi-stationary approximation. Frictional pressure drops of a flow into LHR are negligible. The two-phase flow into LHR has homogeneous equilibrium structure. The single-phase medium (steam) is a special case of the considered model.

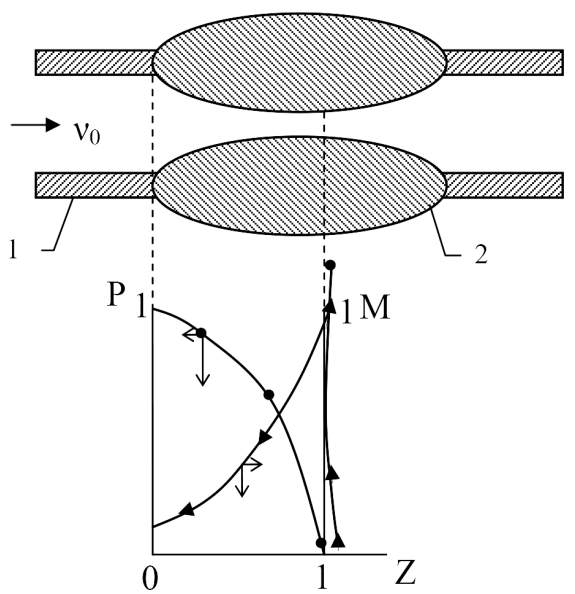

Figure 1 - Conditions for water hammers in the transonic modes of a two-phase steam-liquid flow: 1 - Pipeline, 2 - Local hydrodynamic resistance 
The following systems of NPP can be analogues of such design model:

Armature of passive part of an emergency core cooling system,

Pipeline system "steam-generator - main steam isolation valve" in emergency operation,

Pilot-operated relief valve of the pressurizer of a nuclear reactor in emergency operation,

Steam dump devices of the turbine plant in emergency operation,

Turbine plant drainage systems for saturated condensate, etc

Under the accepted assumptions, the fundamental equations of conservation laws of a two-phase flow are [12]:

$$
\begin{gathered}
\frac{d \rho \Pi v}{d z}=0, \\
\frac{d \rho \Pi v^{2}}{d z}=-\Pi \frac{d P}{d z}, \\
\frac{d}{d z}\left(\rho i+\frac{\rho v^{2}}{2}\right)=0, \\
v(z=0)=v_{0}, \\
P(z=0)=P_{0}, \\
i(z=0)=i_{0},
\end{gathered}
$$

where v, $P$ are speed and pressure of a two-phase homogeneous flow, respectively, $\rho(R, x)$ is density of a two-phase flow, $i(R, x)$ is specific enthalpy of a two-phase flow, and $x$ is mass steam content of a two-phase flow.

After transformations, the decisions (1) - (6) in a criteria format:

$$
\begin{gathered}
\frac{\mathrm{d} \mathbf{P}}{\mathrm{d} \mathbf{z}}=\frac{\mathbf{K}_{\mathrm{v}} \rho \mathbf{v}^{2}}{\left(1-\mathbf{M}^{2}\right)} \mathbf{K}_{\Pi}=\operatorname{grad}(\mathbf{P}) \\
\frac{d \mathbf{v}}{d \mathbf{z}}=-\operatorname{grad}(\mathbf{P}) \frac{\mathbf{v}}{\mathbf{p}}\left(\frac{\partial \mathbf{p}}{\partial \mathbf{P}}+\frac{1}{2 r} \frac{\partial \mathbf{p}}{\partial x}\right)-\mathbf{v} \mathbf{K}_{\Pi}, \\
\frac{d x}{d \mathbf{z}}=-\frac{i_{0}}{2 r} \operatorname{grad}(\mathbf{P}), \\
\mathbf{P}(\mathbf{z}=0)=1 ; \mathbf{v}(\mathbf{z}=0)=1 ; x_{0}(\mathbf{z}=0)=\left(i_{0}-i_{1}\right) / r,
\end{gathered}
$$

where $\mathbf{P}=P / P_{0}, \mathbf{z}=z / L$ ( $L$ is length of convergent section of LHR), $\rho=\rho / \rho_{0}, v=v / v_{0}, \mathbf{i}=i / i_{0}, \Pi=\Pi_{0} / \Pi$.

Criteria of flow transonic modes:

$$
\mathbf{K}_{\mathrm{v}}=\frac{\rho_{0} v_{0}^{2}}{P_{0}} ; \mathbf{K}_{\Pi}=\frac{1}{\Pi} \frac{\mathrm{d} \Pi}{\mathrm{d} \mathbf{z}}, \mathbf{M}=\frac{v}{a}-\text { Mach criterion, (11) }
$$

where $a=\sqrt{\frac{\partial \rho}{\partial P}+\frac{1}{2 r} \frac{\partial \rho}{\partial x}\left(1-x \frac{\partial i}{\partial P}\right)}$ is sonic speed in a twophase homogeneous equilibrium flow, and $r=i_{v}-i_{1}$ is latent heat of steam generation.

The found decisions (7) - (10) are resulted in followings: pressure and steam content of a flow decrease longwise the channel, and flow rate increases in convergent section of $\operatorname{LHR}\left(\mathrm{K}_{\Pi}<0\right)$. When flow rate reaches transonic values $(\mathrm{M} \rightarrow 1)$, modules of flow rate gradients increase sharply; and when flow rate reaches transonic mode $(M=1)$, there is the subsequent sharp stagnation of a flow $(v \rightarrow 0)$ and the local pulse growth of pressure and condensation of a steamliquid flow ("condensation shock" as a result of aperiodic thermohydrodynamic instability of the transonic modes of steam-liquid flows). Thus, a necessary condition for $\mathrm{WH}$ on the equipment of pipeline systems in the transonic modes of two-phase flows is:

$$
\mathbf{M}=1
$$

For modelling the WH parameters (a hydrodynamic load $\Delta P_{\mathrm{g}}$, rates of change of $P$ and $v$ ), it is reputed that when stagnation kinetic energy of a two-phase flow transfers into energy of "condensation shock". Then the balance equations of mass, pressure pulse and energy into "condensation shock":

$$
\begin{gathered}
L \frac{d \rho}{d t}=\rho v-\rho v_{c}, \\
L \frac{d \rho v}{d t}=-\Delta P_{g}(t), \\
\frac{d}{d t}\left(\frac{\rho v^{2}}{2}+\rho i\right)=0,
\end{gathered}
$$

where $t$ is time, $v_{\mathrm{c}}$ is LHR output flow rate, $L$ is channel length before the section of the transonic mode, and $\Delta P_{\mathrm{g}}(t)$ is amplitude of a hydrodynamic load for WH.

Initial conditions for $\mathrm{WH}(\mathbf{M}=1)$ :

$$
v(t=0)=a .
$$

Assumed conservatively (i.e. reliability margin) that WH processes are isothermal, steam condensation is "instantaneous", and a flow rate after "condensation shock" against a LHR input flow rate is negligible, after transformation (13) - (16) in a criteria form are:

$$
\begin{gathered}
\frac{d \mathbf{P}}{d \mathbf{t}}=\mathbf{v}, \\
\frac{\mathrm{d} \mathbf{v}}{\mathrm{dt}}+\mathbf{K}_{1} \mathbf{v} \frac{\mathrm{d} \mathbf{P}}{\mathrm{dt}}=-\Delta \mathbf{P}_{\mathrm{g}}(\mathbf{t}), \\
\mathbf{v} \frac{d \mathbf{v}}{d \mathbf{t}}+\frac{\mathbf{K}_{1}}{2} \mathbf{v}^{2} \frac{d \mathbf{P}}{d \mathbf{t}}+\mathbf{K}_{2} \frac{d \mathbf{P}}{d \mathbf{t}}=0,
\end{gathered}
$$

For initial conditions

$$
\mathbf{v}(\mathbf{t}=0)=\frac{a}{v_{m}}=\mathbf{v}_{g 0}, \mathbf{P}(\mathbf{t}=0)=\mathbf{P}_{g 0}, \mathbf{i}(\mathbf{t}=0)=\mathbf{i}_{g 0},
$$

where

$\mathbf{P}=\frac{P}{P_{m}}, \quad \mathbf{v}=\frac{v}{v_{m}}, \mathbf{t}=\frac{t}{t_{m}}, \mathbf{i}=\frac{i_{1}}{i_{m}}, \quad \mathbf{K}_{1}=\frac{P_{m}}{\rho_{1} a_{1}^{2}}, \quad \mathbf{K}_{2}=\frac{d \mathbf{i}}{d \mathbf{P}}$,

$\rho_{1}, a_{1}$ are density and sonic speed of a fluid phase, respectively. Scales of WH parameters follow from transformations of the equations (16) - (18) to a criteria form:

$$
P_{m}=P_{0} ; v_{m}=\frac{P_{0}}{\rho_{1} a_{1}} ; t_{m}=\frac{L}{a_{1}} ; i_{m}=\frac{P_{0}^{2}}{\rho_{1} a_{1}^{2}} \text {. }
$$


The current and maximum relative amplitudes of a hydrodynamic load in steam-liquid flow transonic modes follow from the solution of combined equations (17) - (21):

$$
\begin{gathered}
\Delta \mathbf{P}_{g}(\mathbf{t})=\int_{0}^{t} \mathbf{v}(\tau) d \tau \\
\frac{d \mathbf{v}}{d \mathbf{t}}+\frac{\mathbf{K}_{1}}{2} \mathbf{v}+\mathbf{K}_{2}=0, \quad \mathbf{v}(\mathbf{t}=0)=\frac{\rho_{1} a_{1} a}{P_{0}} .
\end{gathered}
$$

Sufficient condition for $\mathrm{WH}$ in the transonic modes of a two-phase steam-liquid flow is:

$$
\Delta \mathbf{P}_{g}(\mathbf{t}=1) \geq 1
$$

Against traditional approach for definition of hydrodynamic WH loads due to increase in local hydrodynamic resistances (for example, Zhukovskiy formula [1]), the found decisions consider:

Necessary and sufficient conditions for WH (12), (24) and the corresponding amplitudes of hydrodynamic loads on the equipment and elements of pipeline systems in case of two-phase steam-liquid flows,

Transfer of kinetic energy of a flow stagnation to WH pulse energy.

The latter provision determines much greater estimated hydrodynamic WH loads against Zhukovskiy formula [1].

Generally, numerical methods of modelling are useful to decide (7) - (10), (22), (23) for definition of conditions and consequences of $\mathrm{WH}$ in the two-phase steam-liquid modes. Results of numerical integration of combined equations (7) - (10), (22), (23) by Runge-Kutta method are given as an example in Fig. 1. The figure shows results for the transonic mode of a two-phase steam-liquid flow at $\mathrm{K}_{v}=1$, a convergent section of LHR with $\Pi_{\min } / \Pi_{0}=0.5$ and $L=0.25 \mathrm{~m}\left(\mathrm{~K}_{\Pi}=4\right)$. Disclosure of uncertainty of integration of the equations (7) (10) was carried out at $\mathrm{M}=1$ based on L'Hospital rule.

Consequently, we found that flow rate and steam content increase longwise a convergent section, and pressure decreases. When flow rate reaches transonic values $(\mathrm{M} \rightarrow 1)$, modules of gradients of flow rate and pressure increase significantly; and when transonic mode is reached in the minimum section of LHR $\Pi_{\min }(M=1)$, there is "condensation shock" followed by

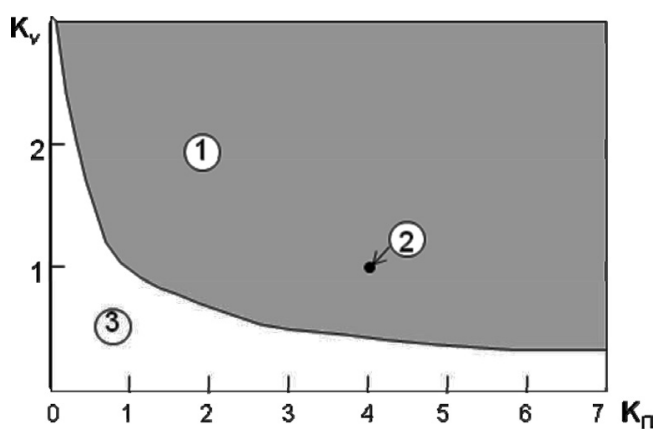

Figure $2-$ Range of criteria for water hammers because of aperiodic instability in the transonic two-phase steam-liquid flows: 1 - Area of water hammers, $2-$ Rated mode at $\mathrm{K}_{\mathrm{N}}=1$, $\mathrm{K}_{\Pi}=4, \Pi_{\min } / \Pi_{0}=0,5, \mathrm{~L}=0,25 \mathrm{M}$ (see Fig. 1), 3 - Area of no water hammers the local pulse growth of pressure and a flow stagnation. Thus, a necessary condition for WH is generated because of aperiodic instability in transonic two-phase (steam-liquid) flows.

Fig. 2 presents the rated range of the initial key modelling criteria $\mathrm{K}_{\checkmark}$, and $\mathrm{K}_{\Pi}$ met necessary and sufficient conditions for WH (12), (24) because of aperiodic instability in transonic adiabatic flashing steam-liquid flows.

\section{Conclusions}

1. The analysis of well-known studies in modelling of conditions for water hammers in equipment and elements of pipeline systems has found that definition of conditions and parameters of water hammers in the transonic modes of single- and two-phase flows (at a speed of propagation of acoustic disturbances) is the least studied problem.

2. The original method is proposed for determining the conditions and parameters of water hammers in transonic flow modes subject to the transition of the kinetic energy of the flow stagnation into the energy of the water hammer pulse.

3 . It is found the simulated hydrodynamic loads in transonic modes can significantly exceed the corresponding known recommendations of N. Zhukovskiy.

4. The computational modelling of the equations of the proposed method has determined the range of the criteria for water hammers due to aperiodic thermohydrodynamic instability in transonic flow modes.

\section{References}

1. Zhukovsky, N. (1949). About hydrodynamic impact in water supply systems. Moscow, GITTL, 100 p.

2. Khachaturyan, S. (1983). Wave processes in compressor units. Moscow: Mashinostroenie, $222 \mathrm{p}$.

3. Accidents at boiler inspection facilities and preventive measures. Gosgortechnadzor Notification Letter. Moscow: Nedra, 1965, 174 p.

4. Screening reactor steam/water piping systems for water hammer. NUREG/CR-6519, 1997.

5. Van Duyne, D., Yow, W., Sabin, J.W. (1992). Water hammer prevention, mitigation and accommodation. Plant water hammer experience, EPRI Report NP-6766, V.1.

6. Ghidaoui, M. (2005). A review of water hammer theory and practice. Applied Mechanics Reviews, V. 58, No. 1, p. 49-76.

7. Bezrukov, Yu., Lisenkov, E., Seleznev, A. (2009). Analysis of the possibility of water hammer in the primary side of VVER reactors. Ensuring safety of VVER NPPs. Proceedings of the 6th Int. ScientificTechn. Conf. Podolsk, Russia, OKB "Hydropress".

8. Korolyov, O., HuiYu, Zh (2016). Dynamic damper fluctuation in the pumping systems. Pratsi OPU, 1(48), 35-41.

9. Mazurenko, A., Skalozubov, V., Kozlov, I., Pirkovskiy, D., Chulkin, O. (2017). Determining the Conditions for the hydraulic impacts emergence at hydraulic systems. Problems of the Regional Energetics, 34(2), 98-104.

10. Skalozubov, V., HuiYu, Zh., Chulkin, O., Pirkovskiy, D. (2017). Modelling method of conditions for reliability-critical hydraulic impacts on pumps of thermal and nuclear power plants. Problems of Atomic Science and Technology, No. 4(110), 74-78.

11. Gerliga, V., Khabenskiy, V. (1994). Instability of the coolant flow in power equipment. Moscow: Energoizdat, 288 p.

12. Vasilchenko, V., Yemelianenko, Ye., Skalozubov, V. (2002). Simulation of accidents at nuclear power plants. Odesa: Rezon, $466 \mathrm{p}$.

13. Safwat Hemmat, H., Arustu Asif, H., Husaini Syed, M. (1990). Systematic methodology for diagnosis of water hammer in LWR power plants. Nucl. Eng. and Design, No. 122, 365-376.

14. Prasser, H.-M., Bottger, A., Zschau, J., Baranyai, G., Ezsol, Gy. (2003). Thermal effects during condensation induced water hammer behind fast acting valves in pipelines. $11^{\text {th }}$ Intern. Conf. on Nuclear Engineering, Tokyo, Japan, ICONE11-36310.

15. Korolev, A. (2010). Analysis and modeling of heat and power equipment operating with the two-phase flow. Odesa: Astroprint, $456 \mathrm{p}$.

16. Kovrigkin, Yu., Skalozubov, V. (2003). Thermoacoustic instability of the coolant in VVER cores. Odesa: TPS, $171 \mathrm{p}$. 
Гідродинамічні удари в обладнанні ядерних енергоустановок при трансзвукових режимах течії парорідинних потоків

\section{Скалозубов В.І., Білоус Н.В., Пірковский Д.С., Козлов І.Л.,} Комаров Ю.А., Чулкін О.А.

Одеський національний політехнічний університет, м. Одеса, Україна

На основі аналізу відомих досліджень в області моделювання умов виникнення гідродинамічних ударів в обладнанні і елементах трубопровідних систем встановлено, що найменш вивченим питанням $є$ визначення умов і параметрів гідродинамічних ударів при трансзвукових режимах течії одно- та двофазних потоків (із швидкістю поширення акустичних збурювань).

Запропоновано оригінальний метод визначення умов і параметрів гідродинамічних ударів при трансзвукових режимах течії, що враховує перехід кінетичної енергії гальмування потоку в енергію імпульсу гідродинамічного удару. Встановлено, що модельовані гідродинамічні навантаження при трансзвукових режимах можуть значно перевищувати відповідні відомі рекомендації М.Є. Жуковського.

На основі розрахункового моделювання рівнянь запропонованого методу визначена область значень критеріїв виникнення гідродинамічних ударів унаслідок аперіодичної теплогідродинамічної нестійкості при трансзвукових режимах течіі.

Ключов і слова: гідроудар, трансзвукові режими, ядерні енергоустановки

Гидродинамические удары в оборудовании ядерных энергоустановок при трансзвуковых режимах течения парожидкостных потоков

Скалозубов В. И., Билоус Н. В., Пирковский Д. С., Козлов И. Л., Комаров Ю. А., Чулкин О. А.

Одесский национальный политехнический университет, г. Одесса, Украина

На основе анализа известных исследований в области моделирования условий возникновения гидродинамических ударов в оборудовании и элементах трубопроводных систем установлено, что наименее изученным вопросом является определение условий и параметров гидродинамических ударов при трансзвуковых режимах течения однои двухфазных потоков (со скоростью распространения акустических возмущений).

Предложен оригинальный метод определения условий и параметров гидродинамических ударов при трансзвуковых режимах течения, учитывающий переход кинетической энергии торможения потока в энергию импульса гидродинамического удара. Установлено, что моделируемые гидродинамические нагрузки при трансзвуковых режимах могут значительно превышать соответствующие известные рекомендации Н.Е. Жуковского.

На основе расчетного моделирования уравнений предложенного метода определена область значений критериев возникновения гидродинамических ударов вследствие апериодической теплогидродинамической неустойчивости при трансзвуковых режимах течения.

Ключевые слова: гидроудар, трансзвуковые режимы, ядерные энергоустановки.

Отримано 31.03.2019 